\title{
Carlo Celentano. "I rapporti politici tra gli arsacidi e i regni vassalli del golfo persico nella seconda metà del I secolo d.C."
}

\section{Leonardo Gregoratti}

\section{(2) OpenEdition}

Journals

Electronic version

URL: http://journals.openedition.org/abstractairanica/49728

DOI: $10.4000 /$ abstractairanica. 49728

ISBN: 1961-960X

ISSN: 1961-960X

Publisher:

CNRS (UMR 7528 Mondes iraniens et indiens), Éditions de l'IFRI

\section{Electronic reference}

Leonardo Gregoratti, "Carlo Celentano. "I rapporti politici tra gli arsacidi e i regni vassalli del golfo persico nella seconda metà del I secolo d.C."', Abstracta Iranica [Online], Volume 40-41 | 2019, document 41, Online since 30 October 2019, connection on 17 April 2021. URL: http://

journals.openedition.org/abstractairanica/49728 ; DOI: https://doi.org/10.4000/abstractairanica. 49728

This text was automatically generated on 17 April 2021

Tous droits réservés 


\title{
Carlo Celentano. "I rapporti politici tra gli arsacidi e i regni vassalli del golfo persico nella seconda metà del I secolo d.C."
}

\author{
Leonardo Gregoratti
}

\section{REFERENCES}

Carlo Celentano. "I rapporti politici tra gli arsacidi e i regni vassalli del golfo persico nella seconda metà del I secolo d.C." in M. Bellomo (ed.). Studi di storiografia e storia antica. Omaggio a Pier Giuseppe Michelotto. Roma: Arbor Sapientiae, 2018, p. 71-83

1 The young researcher reflects about the so-called southern Parthian vassal kingdoms, Persis, Elymais and Characene and their connection with the Persian Gulf and the international trade. A series of coins mint by a certain Vologases, lord, and found at Shiraz in Persis, is to connect with Great King Vologases I's policy in the second half of the 1st century $\mathrm{AD}$, aimed at gaining control over the Persian Gulf sea routes though the increasing Parthian influence on the southern Parthian vassal kingdoms. Within the same context are to be seen the occupation of Characene in the last decades of the century, mentioned by Chinese sources and the foundation of a pro-Arsacid dynasty in Elymais, whose members were allowed to control the important trade hub of Susa. 


\section{AUTHORS}

\section{LEONARDO GREGORATTI}

Durham University 